\title{
Bankaların Ücret Ve Komisyon Gelirlerinin Muhasebeleştirilmesi Ve Finansal Göstergelere Etkisi
}

\section{Ozan ÖZDEMIR*}

\section{ÖZET}

Bankalar ekonomik yapı içerisinde fon fazlası olan mevduat sahipleri ile fon talebi olan kredi müşterilerini bir araya getirme fonksiyonunu yerine getirirken faiz gelirleri ve faiz giderleri ile karşı karşıyadır. Finansal sistem içinde rekabet eden bankaların sadece faiz gelirlerine odaklanmast finansal hedeflere ulaşmasını sınırlandırır. Bununla birlikte bankalar finansal sitemdeki gelişmeler ve talepler doğrultusunda farklı ürünler ve hizmetler sunmaktadır. Bankalar faiz gelirlerinin yanı sira yerine getirdikleri farkl finansal hizmetler ve sundukları ürünler karşılığında ücret, komisyon ve masraf gibi faiz dışı gelirler de elde etmektedir.

Bankalara özgü tekdüzen hesap planı uygulamalarının genel özellikleri, tekdüzen hesap planı çerçevesinde alınan ücret ve komisyonların nasıl muhasebeleştirildiğine dair örneklerin yer aldiğı bu çalışmada bankacılık sektöründe ücret ve komisyon gelirleri ile faiz gelirlerinin zaman içerisindeki gelişimi, alınan ücret ve komisyonlardan elde edilen gelirler ile ilişkili hesap kalemlerindeki trend değişimleri ve oransal değişimler analiz edilmiştir. Araştırmanın son kısmında bankaların aldıkları ücret ve komisyonların finansal performans göstergelerine etkisinin olup olmadı̆̆ istatistiksel olarak analiz edilmiştir. Gelirler.

Anahtar Kelimeler: Bankaların Ücret ve Komisyonları Muhasebeleştirmesi, Finansal Analiz, Faiz Dışı

JEL Sinıflandırması: M41, G21, C51.

\section{Accounting Practices And Effects To Financial Indicators Of Banks' Fee And} Commission Incomes

ABSTRACT

Banks in economic system are faced with interest incomes and interest expenses while performing function of bringing together depositors with fund surplus and credit customers who request fund. Just focusing on the interest incomes of the banks competing within financial system, limits the access to financial goals. In addition to this, banks offer different products and services towards developments and demands in the financial system. Banks also obtaine non-interest incomes such as fees, commissions and costs in exchange for fulfillment of various financial services and products they offer, as well as the interest income.

Development over time of the interest incomes and fee and commission incomes in the banking sector, ratios and trend changes in balance sheet items related with the revenue obtained from fees and the commissions were analyzed in this study that general characteristics of uniform accounting plan practices specific to the banks, examples of accounting practices related the fees and commissions taken in the framework of the uniform accounting plan are included. In the last part of the study, it is analyzed statistically whether there is an effect of fee and commission incomes to the financial performance indicators or not.

Keywords: Accounting Practices Related The Fees And Commissions Of Banks, Financial Analysis, Non-Interest Income.

Jel Classification: M41, G21, C51.

\footnotetext{
* Yrd. Doç. Dr. Ozan Özdemir, Süleyman Demirel Üniversitesi, İktisadi ve İdari Bilimler Fakültesi, ozanozdemir@sdu.edu.tr
} 


\section{GíRiş}

Bankalar mali sistem içerisinde fon fazlası olan tarafların fonlarını, fon talep edenlere ulaştırarak hayati bir fonksiyonu yerine getirmektedir ve bu işlemler sonucunda faiz geliri elde etmektedirler. Bankaların varlık nedenleri bu fonksiyona ilave olarak daha geniş yelpazede ele alınabilir, bu nedenleri arasında; kredi talep edenlerin değerlendirilmesi, asimetrik bilgi probleminin çözülmesi, bilgi üretimi, kredi alanların gözetim ve denetiminin yapılması, likidite sağlanması, işlem maliyetlerinin azaltılması, risk yönetimi ve yeni finansal ürünlerin geliştirilmesi yer almaktadır(Kalaycı, 2010:5). 5411 sayılı Bankacılık Kanunu'nda bankaların yürüttüğü faaliyetler ve hizmetler sıralanmıştır bunlardan bazıları; mevduat kabul etme, kredi verme, saklama, kredi kartı, banka kartı çek işlemleri gibi faaliyetlerdir(2005:md.4). Ülkenin ekonomik gelişmişlik düzeyine ve uluslararası entegrasyona bağlı olarak boyutları ve kapsamı değişen farklı nitelikte bankacılık işlemleri gelişmiştir. Bankacılık işlemleri temelde kaynak sağlama işlemleri, kredi işlemleri, mali işlemler ve hizmet işlemleri olarak bölümlenebilir(Sevilengül, 2001:1-2).

Bankalar içinde bulunduğu makro ve mikro çevredeki değişimlerden hızla etkilenmektedir. Ekonomik kriz dönemlerinde ciddi sıkıntılar yaşanmasına rağmen bankacılık sektörü son yıllarda önemli gelişmeler göstermiştir. Türkiye’de Eylül 2014 itibariyle 46 banka faaliyet göstermektedir. Bu bankaların 33'ü mevduat bankası ve 13'ü kalkınma ve yatırım bankasıdır. Eylül 2014 dönemi verilerine göre, bankaların şube sayısı 11.189 ve personel sayıs1 ise 199.099'a yükselmiştir. Söz konusu dönemde ilk beş bankanın toplam aktifler içindeki payı yüzde 58, mevduat içindeki payı yüzde 59 ve krediler içindeki payı ise yüzde 56 düzeyindedir(TBB, 2014). Bankacılık sektöründe liste başı olan kuruluşlar bölgesel düzeyde ve hatta dünyadaki rakipleri ile yarışacak seviyede mali kriterlerle ulaşmıştır. Bankalar gerçekleştirdikleri mali işlemlerinin kayıtlarını ve raporlamalarını bağlı bulundukları mevzuat hükümlerine ve uluslararası muhasebe standartlarına uygun gerçekleştirmek durumundadır.

Bankalar için muhasebeleştirme ve finansal raporlama açısından tekdüzeni sağlama, tek tip bilanço ve gelir tablosunun elde edilmesi, denetim ve gözetim için gerekli olan bilgilerin doğrulanabilir ve denetlenebilir bir şekilde doğrudan ve sağlıklı olarak elde edilmesi, yetkili otoritelerin sağlıklı veri toplayabilmesi, istatistiki bilgilere doğrudan ulaşılması, finansal analiz, risk analizi, verimlilik analizi gibi çeşitli analiz ve yorumlar için ihtiyaç duyulan bilgilerin standart bir şekilde elde edilmesini sağlama amaciyla Tekdüzen Hesap Planı uygulamaya konulmuştur. Bu kapsamda yayımlanan tebliğ ile hesap planındaki hesapların açıklamaları ve kullanım detayları açıklanmıştır. Ancak uygulamada karşılaşılan farklı durumlara göre zaman zaman ek açıklamaların yapılması veya değiş̧ikliklere gidilmesi kaçınılmazdır(BDDK, Tebliğ, 2007). 


\section{BANKALARIN FINANSAL RAPORLAMA UYGULAMALARI KAPSAMINDA ALINAN ÜCRET VE KOMISYYNLARI MUHASEBELEŞTİRMESI}

Bankaların kullandığı kaynağın toplumun tasarruflarından oluşması ve bu tasarrufları ekonomik yatırımlara yönlendiren kurumlar olması, bankaların muhasebe kayıtlarına gösterilen özen ve dikkati kamu otoriteleri nezdinde daha da arttırmaktadır. Bu bağlamda bankaların faaliyetleri Bankacılık Kanunu ile düzenlenmiş ve bankaların muhasebe sistemi de diğer işletmelerden farklı olarak hazırlanmış özel mevzuatla sıkı kurallara ve gözetime tabi tutulmaktadır(Güney, 2009:2).

\subsection{Bankaların Genel Finansal Raporlama Uygulamaları}

Bankalar, uluslararası standartlar esas alınarak belirlenecek usul ve esaslara uygun olarak muhasebe sistemlerinde tekdüzeni uygulamak; tüm işlemlerini gerçek mahiyetlerine uygun surette muhasebeleştirmek; finansal raporlarını bilgi edinme ihtiyacını karşılayabilecek biçim ve içerikte, anlaşılır, güvenilir ve karşılaştırılabilir, denetime, analize ve yorumlamaya elverişli, zamanında ve doğru şekilde düzenlemek zorundadır. Bu kapsamda yetkili otorite olan Kamu Gözetimi Muhasebe ve Denetim Standartları Kurumu'nun yayınlamış olduğu ve yürürlüğe giren muhasebe standartlarına göre muhasebeleştirilmesi esastır(KGK,2014).

Banka muhasebesi genel olarak altı temel fonksiyona sahiptir. Bunlar(Güney, 2009:2);

- Varlık ve kaynakların izlenmesi,

- $\quad$ Borç ve alacakların izlenmesi,

- $\quad$ Kar ve zarar tespiti,

- $\quad$ Ödenecek vergi ve harçların takibi,

- Diğer şahıslar adına kıymetlerin izlenmesi,

- $\quad$ Plan, bütçe, verimlilik ve maliyet analizlerinin yapılmasıdır.

Tüm bankalar için muhasebeleştirme ve mali raporlama açısından tekdüzeni sağlama, denetim ve gözetim için gerekli olan bilgilerin doğrulanabilir, karşılaştırılabilir ve denetlenebilir biçimde doğrudan ve sağlıklı olarak elde edilebilmesini sağlamak, her türlü analiz ve araştırmalarda standart biçimde ulaşabilmek için bankalara özgü tekdüzen hesap planı kullanılmaktadır. Bu hesap planının yapısında aşağıda belirtilen gruplar yer almaktadır(Kesimli, 2012:23):

Tablo 1: Bankalarda Bilanço Hesapları

\begin{tabular}{|l|lll|}
\hline \multicolumn{3}{|c|}{ Aktif Hesaplar } & \multicolumn{3}{|c|}{ Pasif Hesaplar } \\
\hline 0. DÖNEN DEĞERLER & 3. MEVDUAT VE DĬĞER & YABANCI \\
1. KREDİLER & KAYNAKLAR & & \\
2. YATIRIM AMAÇLI DEĞERLER VE DİĞER & 4. ÖZKAYNAKLAR & & \\
AKTİFLER & & & \\
\hline
\end{tabular}


Tablo 2: Gelir Tablosu Hesapları ve Nazım Hesaplar

\begin{tabular}{|l|}
\hline GELİR TABLOSU HESAPLARI \\
\hline 5. FAİZ GELIRLERİ \\
6. FAİZ GIDERLERİ \\
7. FAİZ DIŞI GELİRLER \\
8. FAİZ DIŞI GIDERLER \\
\hline 9. BİLANÇO DIŞI HESAPLAR(Nazım Hesaplar) \\
\hline
\end{tabular}

\subsection{Alınan Ücret, Komisyon ve Masrafların Muhasebeleştirmesi}

Son yıllarda, bankacılık gelir yapısı içerisinde toplam gelirler içerisinde geleneksel gelir kalemlerinde önemli bir azalma söz konusudur. Toplam işletme gelirleri içerisinde faiz gelirleri yüzdesel olarak düşüş gösterirken, faiz dışı gelirler önemli ölçüde artmıştır. 1980 yılında ABD bankacılık sektöründe faiz dışı gelirlerin, faaliyet gelirleri içerisinde yüzde 20 paya sahip iken 2004'te yüzde 42'ye yükselmiştir (Stiroh, 2006).

Bankalar son y1llarda geleneksel faaliyetlerinin yanı sıra sigorta ürünleri, fon yönetimi hizmetleri, menkul kıymet işlemleri gibi geleneksel olmayan hizmetleri de sunma yönünde daha aktif olmaktadır. Bu durum faiz gelirleri dışında gelirlerin elde edilmesi durumunu ortaya çıkarmıştır. Bankaların bu gelirleri artan bir seyir izlemektedir ve bu gelişmede bankacılık sektörünün kendine özgü koşulları, makro ekonomik değişmeler de etkili olmaktadır (Allen ve Santomero, 2001:290-291). Bankaların hasılat girişleri içerisinde faiz gelirleri kaleminde bir azalma olması durumunda, bu açığın alınan ücret, komisyon ve masraflardan elde edilecek gelirlerle kapatılması banka işletmeleri için önemli bir mali politikadır(Williams ve Rajaguru, 2012:117-118). Avrupa bankaları üzerine yapılan bir araştırmada, bankaların kredi fiyatlama ve faiz marjlarının belirlenmesinde yoğun rekabet koşulları ile karşılaştıkları tespit edilirken, rekabet koşullarında avantaj sağlamak için ücret ve komisyona dayalı gelir üreten ürünler üreterek ürün çeşitlendirmeye gittikleri görülmüştür. Aynı çalışmada araştırma sonucunda faiz dışı gelirler ile kredi faiz oranları arasında ilişki kurulamamıştır(Lepetit vd., 2008:2334).

Türkiye Bankacılık Sisteminde bankalar tarafından alınan ücret, komisyon ve masraflar kamuoyu, medya, tüketici hakem heyetleri vb. birçok platformda gündeme gelirken, çok çeşitli kalemler altında bu tür ücret, komisyon ve masrafların alındığı görülmüştür. Bankacılık Düzenleme ve Denetleme Kurumu(BDDK) tarafindan yapılan açılamayla daha önce alınan bazı önemli ücret kalemlerinin alınamayacağı açıklanmıştır. Bu ücretlerden bazıları şunlardır; ipotek fek ücreti, kiralık kasa ziyaret ücreti, bozuk para tümleme ücreti, borcu yoktur yazısı ücreti, dekont yazdırma ücreti, hesap bakım ücreti, hesap özeti gönderim ücreti, sms gönderim ücreti, hesap işlemsizlik ücreti, hesap cüzdanı yazdırma ücreti, banka kartı ücreti, hesap açma-kapama ücreti, dosya masrafi, kredi istihbarat ücreti vb.

Bankalar, tüketici kredisi veren finansal kuruluşlar ve kart çıkaran kuruluşlar, finansal tüketiciye sunulan ürün veya hizmetler karşılığında farklı başlıklar altında ücretler tahsil 
etmektedir. Türkiye'de bu konuda yetkili otorite olan Bankacılık Düzenleme ve Denetleme Kurumu, "Finansal Tüketicilerden Alınacak Ücretlere İlişkin Usul ve Esaslar Hakkında Yönetmelik" yayımlayarak uygulama birliğini sağlamıştır. Bu yönetmelikte kuruluşlar tarafından ücretlendirilebilecek olan ürün veya hizmetler toplamı 20 kalemden oluşan 5 başlık altında sınıflandırılmıştır. Buna göre(BDDK, Ekim 2014);

Tablo 3: Bankaların Ücretlendirebildiği Ürün veya Hizmetler

\begin{tabular}{l}
\hline Ürün veya Hizmet Sınıflandırmaları \\
\hline 1. Bireysel Krediler \\
\hline 1.1. Tahsis Ücreti \\
1.2. Ekspertiz Ücreti \\
1.3. Taşınır ve Taşınmaz Rehin Tesis Ücreti \\
\hline 2. Mevduat/Katılım Fonu \\
\hline 2.1. Hesap İşletim Ücreti \\
2.2. Para Çekme Ücreti \\
\hline 3. Para Transferleri \\
\hline 3.1. Elektronik Fon Transferi Ücreti \\
3.2. Havale Ücreti \\
3.3. Swift Ücreti \\
\hline 4. Kredi Kartları \\
\hline 4.1. Yıllık Üyelik Ücreti \\
4.2. Ek Kart Yıllık Üyelik Ücreti \\
4.3. Kart Yenileme Ücreti \\
4.4. Nakit Avans Çekim Ücreti \\
5. Diğer \\
\hline 5.1. Kiralık Kasa Ücreti \\
5.2. Kampanyalı Ürün veya Hizmetler Ücreti \\
5.3. Fatura Ödeme Ücreti \\
5.4. Arşiv - Araştırma Ücreti \\
5.5. Onaya Bağlı Bildirim Ücreti \\
5.6. Başka Kuruluş ATM'sinden Yapılan İşlem \\
Ücreti \\
5.7. Kamu Kurum ve Kuruluşlarına Yapılan \\
Ödemeler \\
5.8. Üçüncü Kişilere Yapılan Ödemeler \\
\hline
\end{tabular}

Bankalar finansal tüketiciden aldıkları ücret, komisyon ve masrafları hesap planının 7 FAİZ DIŞI GELİRLER grubunda yer alan ilgili büyük defter hesaplarında(700-749, 760-761 ve 790-791) muhasebeleştirir. Her grup içerisinde yer alan hesaplar, Türk Parası ve Yabancı 
Para olarak ikiye ayrılmıştır. Türk Parası ve Yabancı Para işlemler için çalışan hesaplar, 700 Türk Parası, 701 Yabancı Para örneğinde olduğu gibi, defteri kebir seviyesinde belirlenmiştir. Defteri kebir hesaplarının son hanesi çift sayı ise Türk Parası hesapları, tek sayı ise yabancı para hesapları ifade eder. Bankaların gerçekleşen işlemler sonucunda, finansal tüketiciden aldıkları ücret, komisyon ve masrafları kaydedebileceği hesaplara aşağıda yer verilmiştir(Yıldırım, 2008:259-265);

700-701 İSKONTO VE İ̧TIRA SENETLERINDEN ALINAN KOMISYON

702-703 FAKTORING ALACAKLARINDAN ALINAN ÜCRET VE KOMISYON

710-743 KREDILLERDEN ALINAN ÜCRET KOMISYON

744-745 YENIDEN YAPILANDIRILAN VE İTFA PLANINA BAĞLANAN KREDILERDEN ALINAN ÜCRET VE KOMISYONLAR

746-747 TASFIYE OLUNACAK ALACAKLAR (Tahsili Şüpheli Alacaklardan alınanlar dahil) ile ZARAR NITELIĞİNDEKI KREDILER VE DIIĞER ALACAKLARDAN ALINAN ÜCRET VE KOMISYONLAR

748-749 NAKDİ OLMAYAN KREDILLERDEN ALINAN ÜCRET VE KOMISYONLAR

760-761 BANKACILIK HIZMET GELIRLERİ

790-791 DİĞER FAİZ DIŞI GELİRLER

\section{Bankalar Tarafindan Alınan Ücret ve Komisyonlar:Örnekler}

Örnek 1: İstanbul Taksim şubesine 5.000 TL havale yapmak isteyen müşteriden 100 TL havale ücreti tahsil edilmiştir. Müşteriden havale tutarı, havale ücreti ve BSMV toplamı nakden tahsil edilmiştir.(BSMV havale ücreti üzerinden $\% 5$ hesaplanmıştır.)

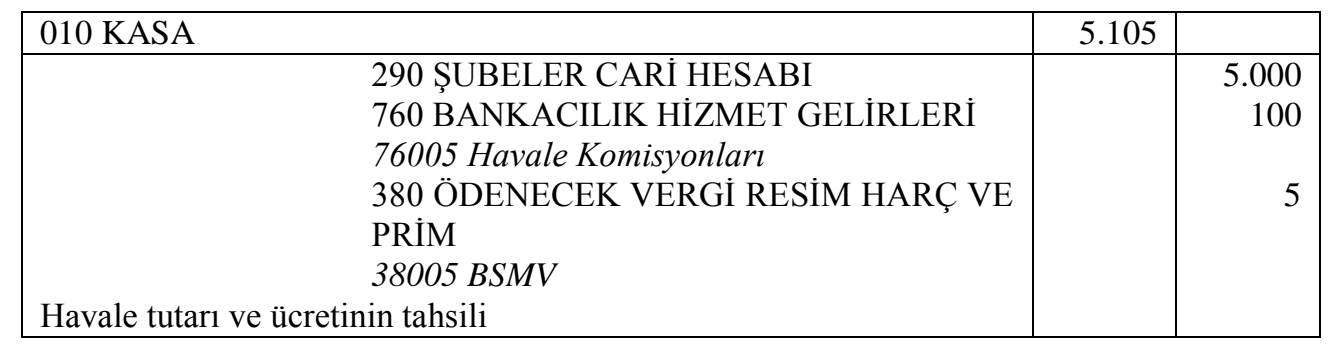

Örnek 2: Ticari mevduat müşterisi CBA A.Ş.'ye teminat mektubu verilmiştir. Verilen teminat mektubu ile ilgili olarak üçer aylık dönemlerde 1.000 TL ve buna bağlı olarak \%5 BSMV hesaben tahsil edilmektedir.

\begin{tabular}{|c|r|r|}
\hline 304 RESMİ TİCARI VE DİĞER KURUMLAR MEVDUATI & 1.050 & \\
\hline 748 NAKDİ OLMAYAN KREDİLERDEN & & 1.000 \\
ALINAN ÜCRET VE KOMİSYONLAR & & \\
74800 TP Teminat Mektubu Komisyonlarl & & \\
380 ÖDENECEK VERGİ RESIM HARÇ VE & & 50 \\
PRIM & & \\
38005 BSMV & & \\
Mart-Haziran dönemi hesaptan tahsil edilen teminat mektubu kom. & & \\
\hline
\end{tabular}


Örnek 3: Banka, daha önce müşteriden senet teminatı alarak kısa vadeli kredi kullandırmıştır. Kredi ile ilgili olarak üçer aylık dönemlerde 20.000 TL faiz ve 2.000TL komisyon tahakkuk ettirmiştir. Faiz ve komisyon tutarı üzerinden hesaplanan \%5 BSMV daha sonra tahsil edilecektir.

\begin{tabular}{|l|r|r|}
\hline $\begin{array}{l}\text { 220 KREDİ FAİZLERİ VE GELİRLERİ TAHAKKKUK VE } \\
\text { REESKONTLARI TP } \\
\text { 278 MUHTELIF ALACAKLAR }\end{array}$ & 1.100 & \\
\hline $514 \quad$ KISA VADELİ DİĞER & & 20.000 \\
KREDİLERDEN ALINAN FAİZLER & & \\
714 KISA VADELİ DİĞER KREDİ. & & \\
ALINAN KOMİSYONLAR & & 2.000 \\
380 ÖDENECEK VERGILLER & & 1.100 \\
Krediye ilişkin faiz, komisyon ve BSMV alacakları & & \\
\hline
\end{tabular}

Örnek 4: 60.000 TL değerinde satış faturasına bağlı alacak için bankaya başvuran müşteri ile faktöring sözleşmesi imzalanmıştır ve 37.500 TL peşin ödeme yapılmıştır. Vade gününde fatura bedeli alıcıdan tahsil edilmiştir. Ödeme günü ile vade arasında geçen süre dikkate alınarak 7.500 TL faktöring ücreti ve BSMV tahsil edildikten sonra kalan tutar müşterinin mevduat hesabına aktarılmıştır. Faktoring belgelerinin(fatura, senet vb.) alınması ve tahsilatı işlemleri nazım hesaplarda takip edilir.

Ödeme Günü

\begin{tabular}{|l|c|c|}
\hline $\begin{array}{l}\text { 278 MUHTELIF ALACAKLAR } \\
\text { 278.99 Diğer Muhtelif Alacaklar } \\
\text {... Faktöring Alacakları }\end{array}$ & 37.500 & \\
\hline \multicolumn{1}{|c|}{ 010 KASA } & & 37.500 \\
Faktöring sözleşmesine dayalı peşin ödemenin yapılması & & \\
\hline
\end{tabular}

Fatura Bedelinin(Alacă̆ın) Tahsil Edilmesi

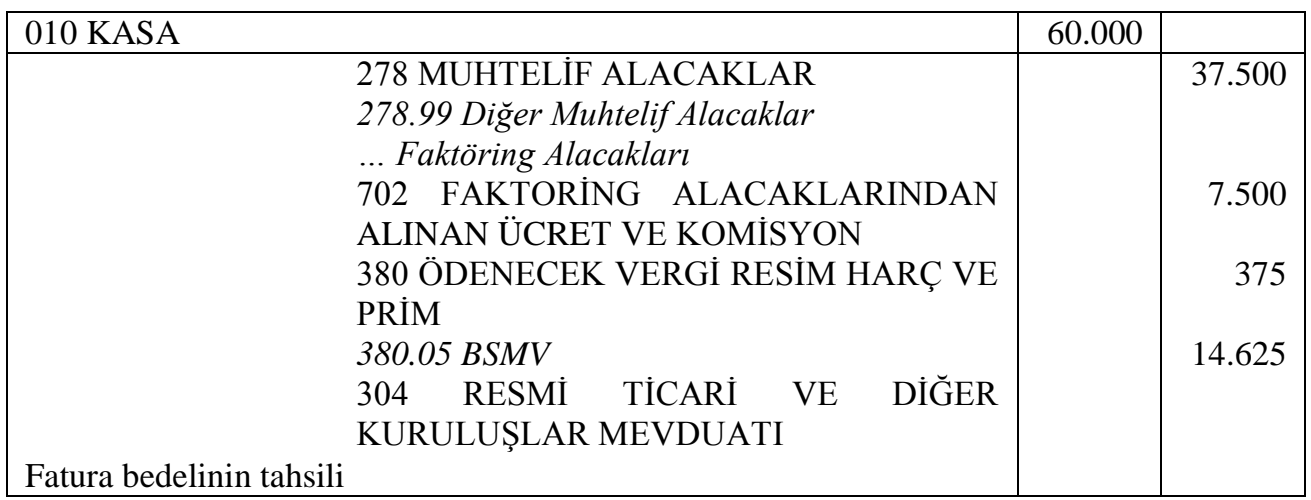




\section{TÜRKIYE BANKACILIK SISTEMINDE ALINAN ÜCRET VE KOMISYONLARIN FINANSAL GÖSTERGELERE ETKISİ}

Araştırmanın amacı, bankaların aldıkları ücret ve komisyon gelirlerinin ilişkili hesap kalemleri ile birlikte zaman içerisindeki seyrini göstermek, ücret ve komisyon gelirlerinin finansal performans göstergelerine etkisinin olup olmadığını incelemektir.

Araştırmanın ilk kısmında net faiz gelirleri, ücret ve komisyon gelirleri ve TÜFE enflasyon oranlarındaki değişimler, ilişkili hesap kalemlerinde ve oranlardaki 10 yıllık değişim analiz edilmiştir. Bu amaçla veri setine "Türkiye Bankacıllk Sistemi”" 2003-2013 Aralık ayına ait(yıllık) ilgili mali tablo kalemlerindeki sektörel toplam veriler dahil edilmiştir. Araştırmanın ikinci kısmında ise, alınan ücret ve komisyon gelirlerinin bankaların finansal performans göstergelerini etkileyip etkilemediği, literatürdeki önceki çalışmalara uygun olarak oluşturulan Regresyon(OLS) modeli ile istatistiksel olarak test edilmiştir. Bu bağlamda, Türkiye Bankalar Birliği’nin 2013 yılına ait aktif büyüklük sıralamasındaki faal 45 bankaya ait o yılın banka mali tablolarındaki ilgili veriler kullanılmış ve SPSS paket programı ile analiz edilmiştir.

\section{1. Ücret ve Komisyon Gelirlerinin Trend ve Oran Analizi}

2003-2013 yıllarına ait ücret ve komisyon gelirleri, net faiz gelirleri ve TÜFE enflasyon verileri endeksi oluşturularak Grafik 1 hazırlanmıştır. Grafikte bankaların almış oldukları ücret ve komisyon gelirleri, net faiz gelirleri ve enflasyon değişiminin incelenebilmesi için baz yıl olarak belirlenen 2003 yllındaki tüm veriler 100 kabul edilerek her bir veri dizisi için endeks oluşturulmuştur.

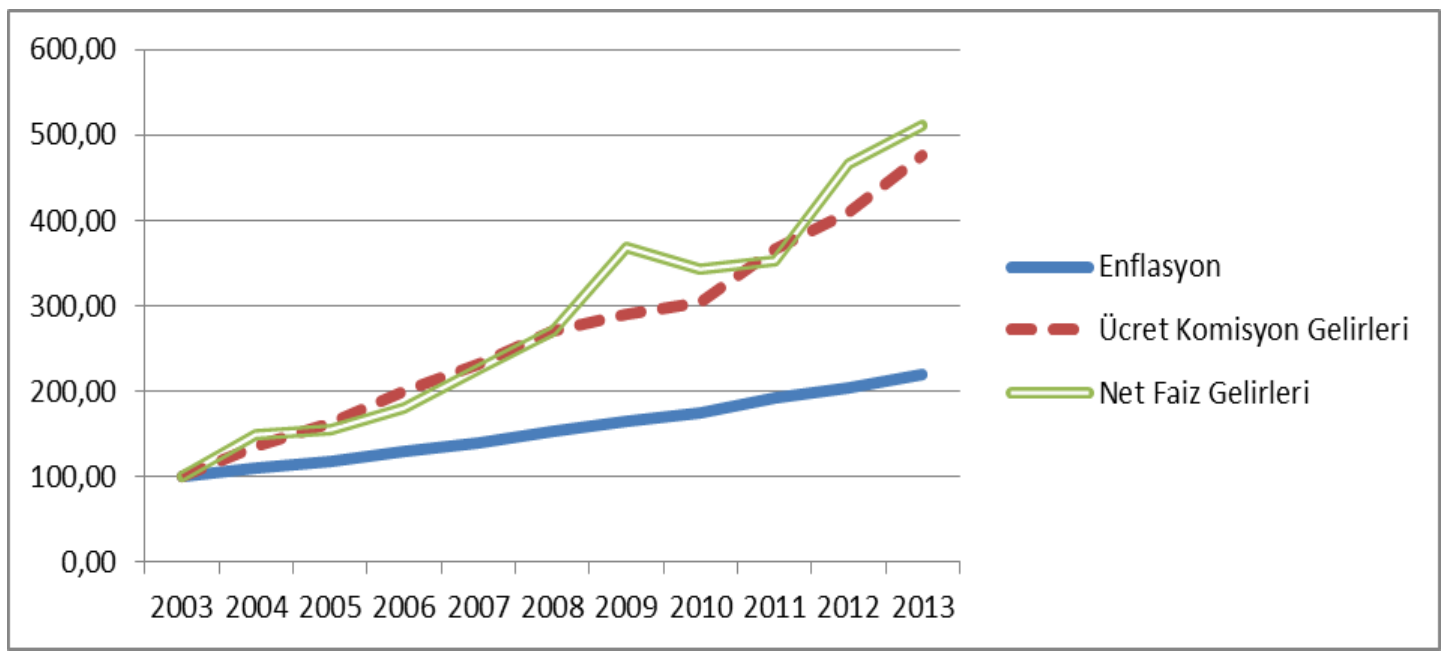

Grafik 1: Bankaların Gelir Kalemleri ve Enflasyon(2003-2013)

Kaynak:TÜFE:www.tuik.gov.tr, Ücret ve Komisyon Gelirleri ve Net Faiz Gelirleri: www.tbb.org.tr’den oluşturulmuştur. 
Grafikten görüleceği üzere TÜFE enflasyon seyri 100 düzeyinden başlayarak belirli bir ivme ile yükselişine devam etmiş 2012-2013 yıllarında 200 bandının üzerine çıkmıştır(2013=220). Net faiz gelirleri ile ücret ve komisyon gelirleri, enflasyon seyrinin üzerinde ve birbirine yakın düzeylerde yükselişine devam etmiştir. 2008-2009-2010 yıllarında net faiz gelirlerindeki yükselişin, ücret ve komisyon gelirlerini aştığı gözlemlenmektedir. 2011 yılında yükseliş seyri bankaların faiz gelirleri ve faiz dışı gelirleri açısından aynı seviyeye geldiği görülürken 2012-2013 yıllarında faiz gelirlerinin, faiz dışı gelirlerden daha yüksek artış gösterdiği görülmektedir. Sektördeki büyümenin ve makroekonomik diğer faktörlerin etkisi ile bankaların gelirlerindeki yükseliş trendini açıklamak mümkündür.

Bankaların mali tablolarındaki ilişkili bazı kalemlerin sektörel trend analizi yapılarak Tablo 4 hazırlanmıştır. 2003 yılı baz yıl olup, bu yıldaki ilgili hesap kalemleri 100 kabul edilmiştir.

Tablo 4: Trend Analizi

\begin{tabular}{lccccccccccc}
\hline & $\mathbf{2 0 0 3}$ & $\mathbf{2 0 0 4}$ & $\mathbf{2 0 0 5}$ & $\mathbf{2 0 0 6}$ & $\mathbf{2 0 0 7}$ & $\mathbf{2 0 0 8}$ & $\mathbf{2 0 0 9}$ & $\mathbf{2 0 1 0}$ & $\mathbf{2 0 1 1}$ & $\mathbf{2 0 1 2}$ & $\mathbf{2 0 1 3}$ \\
\hline Alınan Ücr. Ko. & 100 & 136 & 163 & 201 & 231 & 271 & 290 & 304 & 366 & 409 & 477 \\
Dönem Karı & 100 & 116 & 101 & 205 & 266 & 236 & 363 & 400 & 357 & 424 & 443 \\
Net Faiz Gel. & 100 & 150 & 156 & 181 & 226 & 271 & 369 & 343 & 354 & 467 & 512 \\
Mevduat & 100 & 123 & 158 & 195 & 222 & 282 & 315 & 382 & 435 & 479 & 587 \\
Kredi ve Alac. & 100 & 148 & 219 & 312 & 401 & 524 & 544 & 727 & 949 & 1.099 & 1.451 \\
Aktifler & 100 & 123 & 159 & 194 & 225 & 283 & 320 & 385 & 465 & 520 & 655 \\
\hline
\end{tabular}

Tablo 4'te yer alan alınan ücret ve komisyon gelirleri ile net faiz gelirleri karşılaştırmalı olarak ele alındığında her iki kalemde de yükseliş trendinin devam ettiği görülmektedir. 2010 yılında net faiz gelirlerinin bir önceki yıla göre aşağı yönlü bir kırılma yaptığ1 görülürken, 2011 yılında tekrar yükselmiş ve 2013 yılında hesaplanan değerin, alınan ücret ve komisyon gelirlerinden yüksek bir seviyeye çıktığı görülmektedir. Tüm hesap kalemlerinde genellikle yükseliş eğilimi görülmektedir. Kredi ve alacakların yükseliş ivmesi tabloda yer alan diğer kalemlerin yükselişinden oldukça fazladır. 2003 yılında 100 kabul edilen değer, 2008 yılında 500'ün üzerine, 2013 yılında ise 1.451 değerine kadar yükselmiştir. Kredi ve alacakların bu artışı net faiz gelirleri ile alınan ücret ve komisyon gelirlerini artış yönünde etkilemesi beklenti dahilindedir. Bankaların toplam aktiflerindeki artışın, rakamsal büyüklüklerin de dikkate alınmasıyla önemli düzeyde olduğunu söylemek mümkündür. Bankaların aktif büyüklüğü 2003-2013 arasında yaklaşık 6 katın üzerinde artış göstermiştir.

Bankacılık sektöründe 2003 ve 2013 yılları arasında alınan ücret ve komisyon gelirleri ile net faiz gelirleri ve dönem karı arasındaki oransal ilişkiyi göstermek üzere Tablo 5 hazırlanmıştır.

Tablo 5'ten görüleceği üzere alınan ücret ve komisyon gelirlerinin dönem karına oranında en düşük oranın 2010 yılında(54,71) ve en yüksek oranın 2005 yılında(116,22) ortaya çıktığı görülmektedir. Dönemsel etkilerin veya sektördeki gelişmelerin banka mali 
tablolarına yansımasının dışında, oranın genel olarak 70-80 bandında seyrettiğini ifade etmek mümkündür.

Tablo 5: Bankacılık Sektöründe Ücret- Komisyon Gelirleri ve Faiz Gelirleri ile İlgili Oranların Değişimi

\begin{tabular}{|c|c|c|c|c|c|c|c|c|c|c|c|}
\hline Oranlar & 2003 & 2004 & 2005 & 2006 & 2007 & 2008 & 2009 & 2010 & 2011 & 2012 & 2013 \\
\hline $\begin{array}{l}\text { Alınan Ücret ve } \\
\text { Kom./Kar }\end{array}$ & 71,91 & 83,94 & 116,22 & 70,67 & 62,53 & 82,44 & 57,48 & 54,71 & 73,70 & 69,38 & 77,40 \\
\hline $\begin{array}{c}\text { N.Faiz } \\
\text { Gelirleri/Kar }\end{array}$ & 208,57 & 269,57 & 320,98 & 184,41 & 177,21 & 238,70 & 212,36 & 178,72 & 206,51 & 229,58 & 241,25 \\
\hline $\begin{array}{l}\text { A. Ücret Kom./N. } \\
\text { Faiz Gelirleri }\end{array}$ & 34,48 & 31,14 & 36,21 & 38,32 & 35,29 & 34,54 & 27,07 & 30,61 & 35,69 & 30,22 & 32,09 \\
\hline $\begin{array}{l}\text { A. Ücr K./ (N. } \\
\text { F.G.+A.Ü.K.) }\end{array}$ & 25,64 & 23,75 & 26,58 & 27,70 & 26,08 & 25,67 & 21,30 & 23,44 & 26,30 & 23,21 & 24,29 \\
\hline
\end{tabular}

$\mathrm{Bu}$ analizin dışında dönem karını etkileyen diğer sonuç hesaplarının detaylı incelenmesi sektör hakkında kapsamlı finansal analiz için gerekli olmaktadır. Ancak çalışma kısıtlarından dolayı diğer detaylara yer verilmemiştir. Net faiz gelirlerinin dönem karına oranlanmasında en düşük oran 177,21(2007 yılı) ve en yüksek oran ise 320,98(2005 y111) olarak hesaplanmıştır. Genel olarak bu oranın 200-260 bandında seyrettiğini ifade etmek mümkündür. Alınan ücret ve komisyon gelirlerinin net faiz gelirlerine oranlanması sonucunda 2003-2013 yılları arasında çıkan sonuçların 27-38 bandında olduğu görülmektedir. $\mathrm{Bu}$ bilgiye göre, bankaların, ortalama olarak net faiz gelirlerin 3'te 1 oranında ücret ve komisyon gelirleri elde ettiğini söylemek mümkündür. Ücret ve komisyon gelirlerinin, toplam faaliyet gelirleri ne (ücret ve kom. + net faiz geliri) oranlanması sonucunda ortalamanın \%25 düzeyinde olduğu görülmektedir.

\section{2. Ücret ve Komisyon Gelirleri ile Finansal Performans Göstergeleri İlişkisi}

Araştırmamızın bu kısmında faiz dışı gelirler olarak değerlendirilen ve gelir yapısı içerisinde ürün çeşitlendirme amaciyla yer alan ücret ve komisyon gelirlerinin finansal performansa etkisi olup olmadığına dair araştırma yer almaktadır. Bu kapsamda Türkiye Bankacılık sisteminde 2013 yılı itibariyle faal olan ve Türkiye Bankalar Birliği aktif sıralamasında yer verilen 45 bankanın mali verileri ele alınmıştır. Oluşturulan modelde bankaların finansal performans göstergeleri arasında yer alan özkaynak karlılığı(ROE) ve aktif karlılığı(ROA) oranları ile bankaların finansal istikrarı için gösterge olarak kabul edilen Z-skoru bağımlı değişken olarak kabul edilmiştir(Hannan ve Hanweck, 1988; Nash ve Sinkey,1997).

Özkaynak Karlılığı Oranı ve Aktif Karlılık Oranları riske göre ayarlanmış oranlara dönüştürülerek modele dahil edilmiştir(Stiroh ve Rumble2006).

RARROE $=$ Riske göre düzeltilmiş $\mathrm{ROE}=\frac{\frac{R O E}{\sigma R O E}}{\sigma}$, 
RARROA=Riske göre düzeltilmiş ROA $=\frac{R O A}{\sigma R O A}$,

Z- Skoru $=\frac{\text { ROA+ OZKAYNAKLAR }}{\text { AKTIFLER }}$

Bankaların ürün çeşitliliğini ölçme amacıyla kullanılan Herfindahl-Hirshman endeksi Stiroh ve Rumble(2006) tarafından gözden geçirilerek, DIV(diversity, çeşitlendirme) oranı hesaplanmıştır; Bu oranın hesaplanmasında aşağıdaki yöntem kullanılmaktadır;

$D I V=1-\left(S H_{N E T}^{2}+S H_{N O N}^{2}\right) \mathrm{Bu}$ hesaplamada SHNET net faiz gelirleri oranı ve SHNON faiz dışı gelirler oranı olup aşağıdaki gibi hesaplanmıştır.

$$
S H_{\text {NON }}=\frac{\text { NON }}{\text { NET }+ \text { NON }} \text { ve } S H_{\text {NET }}=\frac{\text { NET }}{\text { NET }+ \text { NON }}
$$

DIV oranın 0,5 olması banka gelirleri içerisinde tam bir ürün çeşitlendirme yapısının olduğunu yani faiz gelirleri ile faiz dışı gelirlerin eşit paylara sahip olduğunu göstermektedir. Değerin 0 olması ise gelir türünün tek çeşitten kaynaklandığını ifade etmektedir. Farklı finansal hizmetler sunan finansal holding ve bankaların ürün çeşitliliğinden dolayı DIV oranının 0,5'e yakın olması beklenir(Delpachitra ve Lester, 2013).

Modelde bağımsız değişkenler(Delpachitra ve Lester, 2013; Stiroh ve Rumble,2006);

Alınan ücret ve komisyonlar: $1.000 \mathrm{TL}$,

DIV endeksi,

SHnon oranı: Faiz dışı gelirlerin toplam gelirlere oranı,

E/A: Özkaynakların Aktiflere Oranı

Aktifler: Aktif toplamı (1.000TL). Analize dahil edilen değişkenlerle ilgili tanımlayıcı istatistikler Tablo 6'da yer almaktadır.

Tablo 6: Tanımlayıcı İstatistikler

\begin{tabular}{ccccccc}
\hline & N & Min & Maks & Ortalama & Std. Sapma & Medyan \\
\hline RAR $_{\text {ROE }}$ & 45 & $-2,57$ & 2,68 & 0,9035 & 1,01130 & 0,8696 \\
RAR $_{\text {ROA }}$ & 45 & $-5,59$ & 2,43 & 0,3095 & 1,01130 & 0,3504 \\
Z-skoru & 45 & 0,20 & 3,05 & 0,8896 & 0,85940 & 0,4656 \\
$\begin{array}{c}\text { Ücret ve } \\
\text { Komisyonlar }\end{array}$ & 45 & 0,00 & $3.135 .783,00$ & $406.583,2667$ & $769.922,92722$ & $19.596,00$ \\
DIV & 45 & 0,00 & 0,48 & 0,2580 & 0,14949 & 0,2743 \\
SHnon & 45 & 0,00 & 0,41 & 0,1717 & 0,11627 & 0,1641 \\
E/A & 45 & 0,06 & 0,97 & 0,2823 & 0,28303 & 0,1460 \\
Aktifler & 45 & $49.886,00$ & $210.500 .037,00$ & $36.341 .557,2667$ & $63.208 .503,94469$ & $5.596 .026,00$ \\
\hline
\end{tabular}

Tanımlayıcı istatistiklere yer verilen Tablo 6'dan da görüleceği üzere RARROE ve RARROA değerlerinde en küçük değerlerin negatif olması bazı bankaların zarar 
açıklanmasından kaynaklanmaktadır. Ücret ve komisyon gelirlerinin en küçük değeri 0 (sıfır) olarak görülmektedir. Veri setinde yer alan bir bankada bu tür bir gelir kalemi açıklanmamıştır. 2013 yılında bir bankanın elde ettiği en yüksek ücret ve komisyon geliri 3.135.783.000 TL'dir. Bankacılık sektöründe, banka başına ortalama ücret ve komisyon geliri ise yaklaşı 407 milyon TL'dir. Toplam aktifleri en yüksek olan banka, 210 milyar TL'nin üzerinde aktife sahiptir. En yüksek DIV değerine $(0,48)$ sahip bankanın gelir yapısı içerisinde faiz gelirleri ve faiz dışı gelirlerinin paylarının birbirine çok yakın olduğu ifade edilebilir.

Bağımlı değişken olarak 3 farklı model alternatifi ile analiz yapılmış olup RARROA modelinde, açıklayıcılık oranının düşük olması ve anlamlılık düzeyinin yeterli olmaması nedeniyle bu model analizden çıkarılmıştır. RARROE ve Z-skoru ile oluşturulan iki farklı modelin sonuçları Tablo 7'de sunulmuştur.

Tablo 7: Regresyon(OLS) Modeli Sonuçları

\begin{tabular}{lcc|cc}
\hline Değişkenler & RAR $_{\text {ROE }}$ & T değeri & Z skoru & T değeri \\
\hline Ücret ve Komisyonlar & $-0,165$ & $-0,460$ & $-0,018$ & $-0,0354$ \\
DIV & 0,140 & 0,861 & 0,021 & 0,902 \\
Özkaynaklar/Aktif & $-0,197$ & $-1,313$ & 1,004 & $46,387^{*}$ \\
Aktifler & 0,581 & $1,687^{* *}$ & 0,019 & 0,392 \\
$\mathrm{R}^{2}$ & $0,37^{*}$ & & $0,98^{*}$ & \\
Durbin Watson & 1,956 & & 2,071 & \\
\hline
\end{tabular}

Tabloda yer alan değerlerin üzerinde yer alan $* * *$ simgeler sirasıyla $\% 5$ ve $\% 10$ anlamlılık düzeylerini ifade etmektedir.

Regresyon modeli sonuçlarının yer aldığı Tablo 7'de yer verilen RARROE bağımlı değişkenin bulunduğu modelin açıklayıcılık oranı 0,37'dir. Ancak modelde yer alan bağımsız değişkenlerden sadece aktif büyüklüğü(TL) anlamlı olarak modele dahil olmuştur (sig:olasılık değeri<0,10). Modele dahil edilen değişkenlerin oto-korelasyonunu test etmek için Durbin Watson katsayısı hesaplanmıştır. Durbin Watson değerinin 1,5-2,5 arasında olması uygundur(Kalaycı, 2005:264). Sonuç olarak özkaynak karlılığının riske göre düzeltilmiş değerlerini bağımlı değişken olarak ele alan birinci modelde aktifler pozitif yönlü bir etkiye sahiptir. Ürün çeşitliğini gösteren DIV endeksi modelde 0,140 katsayıyla yer almıştır ancak olasılık değeri \%10 anlamlılık düzeyinde(\%90 güven aralığında) kabul edilebilir düzeyde değildir. $\mathrm{Bu}$ sonuca göre ürün çeşitlendirmenin finansal performans göstergelerinden RARROE üzerine olumlu etkisinin olduğunu istatistiksel olarak söylemek mümkün değildir.

İkinci modelin(Z-skoru) R2 değeri 0,98 ve Durbin Watson değeri 2,071'dir. Ayrıca model \%5 hata düzeyinde anlamlıdır. Modelde yer alan bağımsız değişkenlerden ücret ve komisyonlar negatif yönlü, diğer değişkenler ise pozitif yönlü etkiye sahiptir. Özkaynaklar/Aktif oranı \%5 hata düzeyinde anlamlıdır ve modelde yer alan T değeri oldukça yüksek düzeydedir(46,387). Bu sonuçlara göre bankaların finansal performanslarını 
değerlendirmede kullanılan $\mathrm{Z}$ skorunun bağımlı değişken olarak yer aldığı modelde özkaynaklar/aktifler oranının anlamlı ve pozitif yönlü bir etkisi olduğu belirtilebilir. Ürün çeşitliğini gösteren DIV endeksi bu modelde 0,021 katsayıyla yer almıştır ancak olasılık değeri \%10 anlamlılık düzeyinde(\%90 güven aralığında) kabul edilebilir düzeyde değildir. Bu sonuca göre ürün çeşitlendirmenin finansal istikrar göstergelerinden Z-skoru üzerine olumlu etkisinin olduğunu istatistiksel olarak söylemek mümkün değildir.

Delpachitra ve Laurence Lester'in(2013) Avustralya bankaları üzerine yaptıkları çalışmada RARROE modelinde DIV değerinin negatif yönlü etkiye sahip olduğu, Z-skoru modelinde ise pozitif katsayının bulunduğu ancak anlamlılık düzeyinde kabul edilebilir olmadığı görülmüştür. Bu çalışmada Z-skoru modelinde Özkaynaklar/Aktifler oranın pozitif katsayıyla modelde yer aldığı da anlamlı bir ilişki olduğu görülmektedir.

Goddard vd.(2008) Amerikan banka ve kredi kuruluşları üzerine yaptıkları benzeri çalışmada aktif büyüklüğüne göre farklı modeller oluşturmuşlardır. Bu çalışmada aktif büyüklüğü 50 milyon doların altındaki bankalarda, ürün çeşitlendirme endeksi değerinin modelde negatif yönlü etkiye sahip olduğu görülmektedir. Stiroh(2004)'un bankalar üzerine yaptığı çalışmada yüksek düzeyde faiz dışı gelirlerin bankaların riske göre düzeltilmiş finansal performanslarında negatif etkisi olduğunu saptamıştır.

\section{SONUÇ}

Bankaların gelir portföyü içerisinde faiz gelirleri temeli oluştururken, finansal piyasalardaki gelişmeler, müşterilerin talepleri, teknolojik gelişmeler vb. nedenlerle farklı finansal ürün ve hizmetler sunarak faiz dışı gelirler de elde etmektedir. Bankalar tarafından daha önceki dönemlerde farklı isimler altında ücret, komisyon ve masraflar alınabilmekteyken, yayımlanan yönetmelik ile finansal tüketicilerden alınacak ücretler ile ilgili usul ve esaslar belirlenmiştir. Bankaların gerçekleştirmiş oldukları mali işlemler, genel kabul görmüş muhasebe ilkeleri ile muhasebe standartlarına uyumlu bir şekilde ve bankalara özgü olarak hazırlanan tekdüzen hesap planına göre kaydedilmekte ve raporlanmaktadır. Bankalar söz konusu gelirleri, tekdüzen hesap planında gelir tablosu hesapları içerisinde 7 Faiz Dışı Gelirler Grubunda yer alan uygun hesaplara alacak kaydetmelidir. Bankaların gelir tablosunda önemli bir grubu oluşturan bu hesaplar sektör uygulamacıları ve diğer ilgililer tarafından önem verilerek analiz edilir.

Alınan ücret ve komisyonlardan elde edilen gelir ve net faiz gelirlerinin sektörel olarak gelişiminin 2003-2013 yıllarındaki seyri incelendiğinde, önemli bir yükseliş trendi göze çarpmaktadır. Alınan ücret ve komisyon gelirleri ile net faiz gelirleri artışının birbirine yakın bir seyirde, enflasyondan ise çok yüksek düzeyde olduğu görülmektedir. Bankaların söz konusu zaman diliminde, aktiflerinde, mevduat rakamlarında özellikle de kredi ve alacak büyüklüklerinde ciddi artış gözlemlenmiştir. Alınan ücret ve komisyon gelirlerinin net faiz gelirlerine oranı ise yıldan yıla çok fazla artış göstermemiştir. 
Bankaların faiz dışı gelirlere ağıllık vererek(ürün çeşitlendirme stratejisi) finansal hedeflerine ulaşması ve/veya finansal göstergelerin daha iyi hale gelip gelmediği literatürde araştırmalara konu olmuştur. Bu bağlamda önceki çalışmalarda yer verilen DIV(ürün çeşitlendirme endeksi) hesaplaması sonuçları ve diğer ilgili değişkenlerin dahil edildiği iki model oluşturulmuştur. Bu modellerin istatistiksel analizi sonucunda; riske göre düzeltilmiş özkaynak karlılığında aktif büyüklüğünün, Z skoru modelinde ise özkaynaklar/aktifler oranının anlamlı ve pozitif yönlü bir ilişkisi olduğu tespit edilmiştir. Ürün çeşitliğini gösteren DIV endeksinin her iki modelde de performans göstergeleri üzerine etki ettiğini istatistiksel olarak ifade etmek mümkün görünmemektedir. Bankaların farklı finansal ürünler ve hizmetler sunarak, faiz dışı gelirlere ağılık vermesinin çalş̧mada yer verilen finansal göstergeler açısından anlamlı ve pozitif yönlü bir ilişkisi tespit edilmemiştir. Ancak bankaların farklı ürün ve hizmetlerle müşterilerine çeşitli kanallarla ulaşmasının, müşterilere yönelik doğru iletişim kanallarının kurulmasının, kurumsal imajın olumlu etkilerinin artması ile müşteri memnuniyetinin artması ve olumlu finansal etkilerinin olacağı beklenir. Konu ile ilgili araştırmacıların yapacakları sonraki çalı̧̧alarda, banka türlerinin, sermaye ve kurumsal yapılarındaki farklı1ıkların, faiz dışı gelirlere yönelmede etki edip etmediği, finansal sistemde uygulamaya geçen yeni ürün ve hizmetlerden elde edilecek ücret ve komisyon gelirlerinin muhasebe uygulamalarını nasıl etkilediği vb. araştırma konularına yer verilebilir.

\section{KAYNAKLAR}

Allen, F. ve Santomero A.M. (2001), “ What do financial intermediaries do?”, Journal of Banking \& Finance, 25, 271-294.

Bankacılık Düzenleme ve Denetleme Kurumu, "Finansal Tüketicilerden Alnacak Ücretlere İlişkin Usûl ve Esaslar Hakkında Yönetmelik”, 03 Ekim 2014 Tarihli 29138 Resmi Gazete.

Bankacılık Düzenleme ve Denetleme Kurumu, "Tekdüzen Hesap Planı ve İzahnamesi Hakkında Tebliğ", 26 Ocak 2007 tarih ve 26415 mükerrer Resmi Gazete.

Bankacıllk Düzenleme ve Denetleme Kurumu, Basın Duyurusu, Sayı 2014/25 (21/8/2014).

Bankacılık Kanunu (5411 Sayıl1), 1 Kasım 2005 tarihli ve 25983 (Mükerrer) sayılı Resmi Gazete.

Delpachitra S. ve Lester L., (2013), "Non-Interest Income: Are Australian Banks Moving Away from their Traditional Businesses?, The Economic Society of Australia, 190199.

Goddard J., McKillop D., ve Wilson J.O.S., (2008), "The Diversification and Financial Performance of US Credit Unions” Journal of Banking \& Finance, 32, 1836-1849.

Güney, A. (2009), "Banka Muhasebesi” İstanbul: Beta Yayıncılı.

Hannan, T. H. ve Hanweck G. A., (1988), "Bank Insolvency Risk and The Market For Large Certificates of Deposit”, Journal of Money, Credit and Banking, May, 203-211. 
Kalaycı, Ş.(2010), "Nedenleri Etkileri ve Sonuçlarıyla Bankacılık Krizleri ve Öncü Göstergeleri”, Ankara: Asil Yayın Dağıtım.

Kalayc1, Ş.(Ed), Öztürk, E,(2005), “Çoklu Doğrusal Regresyon Modeli”, SPSS Uygulamalı Çok Değişkenli İstatistik Teknikleri, Ankara: Asil Yayın Dağıtım.

Kamu Gözetimi Muhasebe ve Denetim Standartları Kurumu, Muhasebe/Finansal Raporlama Standartlar1, http://www.kgk.gov.tr/content_list-208-turkiye-muhasebestandartlari.html, Ekim, 2014.

Kesimli, İ. G.(2012), “Banka Muhasebesi”, İstanbul: Kriter Yayınevi.

Lepetit, L., Nys, E., Rous, P. ve Tarazi, A., (2008), “The Expansion of Services in European Banking: Implications for Loan Pricing and Interest Margins”, Journal of Banking \& Finance, 32, 2325-2335.

R.C. Nash, J. F. Sinkey Jr., (1997), “On Competition, Risk, and Hidden Assets in the Market For Bank Credit Cards”, Journal of Banking \& Finance, 21, 89-112,. 96

Sevilengül, O.(2001), “Banka Muhasebesi”, B:3, Ankara: Gazi Kitabevi.

Stiroh, K.J. (2004), “Diversification in Banking: Is Noninterest Income the Answer?”, Journal of Money, Credit and Banking, 36, 853-82.

Stiroh, K.J. (2006), “A Portfolio View of Banking with Interest and Noninterest Activities”, Journal of Money, Credit and Banking, 38, 1351-61.

Türkiye Bankalar Birliği, Mali Tablo Verileri, http://www.tbb.org.tr/tr/banka-ve-sektorbilgileri/veri-sorgulama-sistemi/mali-tablolar/71(20.12.2014)

Türkiye Bankalar Birliği, Türkiye Bankacılık Sistemi, İstatistiki Raporlar: Üç Aylık Bankacılık Sektörü Bilgileri/Eylül 2014, http://www.tbb.org.tr(20.12.2014).

Türkiye İstatistik Kurumu, TÜFE Enflasyon Verileri, http://www.tuik.gov.tr(20.12/2014)

Williams B. ve Rajaguru G., (2012), “ The Chicken or the Egg? The Trade-off Between Bank Fee Income and Net Interest Margins , Australian Journal of Management 38(1) 99123.

Yıldırım, M. (2008), “Banka Muhasebesi”, İstanbul: Türkiye Bankalar Birliği Yayın No:258. 
